\title{
Imaging spectrum of lung adenocarcinoma with histopathological correlation
}

\author{
V Noble, A Shah", F Mcleod \\ From International Cancer Imaging Society Meeting and 15th Annual Teaching Course (ICIS 2015) \\ London, UK. 5-7 October 2015
}

\section{Learning objectives}

The aim of this pictorial review is demonstrate the radiological appearances of adenocarcinoma with particular focus on more unusual appearances such as cystic adenocarcinoma.

\section{Content organisation}

Non-small cell lung cancers account for almost $85 \%$ of all lung cancers and of these, adenocarcinoma is the most common. This entity has recently been reclassified to reflect increased understanding of the underlying pathology and thus it is crucial for radiologists to understand the new classification, the role of radiology in identifying preinvasive lesions and the guidelines for management of subsolid nodules. We present the spectrum of imaging appearances from ground glass nodules (GGNs) to solid mass lesions with histopathological correlation.

\section{Conclusion}

It is important for radiologists to recognise the spectrum of appearances of lung adenocarcinoma and follow appropriate algorithms for surveillance or further management.

* Correspondence: aartishah1@gmail.com

Oxford University Hospitals NHS Trust, Windmill Road, Oxford, OX3 7LD, UK

Submit your next manuscript to BioMed Central and take full advantage of:

- Convenient online submission

- Thorough peer review

- No space constraints or color figure charges

- Immediate publication on acceptance

- Inclusion in PubMed, CAS, Scopus and Google Scholar

- Research which is freely available for redistribution 